\title{
MENUMBUHKAN MINAT MEMBACA SEBAGAI UPAYA PENINGKATAN MUTU TENAGA PENDIDIK PAUD DI INDONESIA
}

\author{
Cucu Surtiawati*
}

\begin{abstract}
In this information and knowledge era, people tend to develop their expertise by obtaining information and knowledge as much as and as fast as possible. They will stand behind if they do not follow and adapt the advanced science and technology. Reading is a tool to obtain many kinds of information and reading habit is a precondition to build and develop reading society. However, reading has not become a habit aand reading interest is not high enough for most most of people in Indonesia. Reading skill and reading habit of the teachers of early childhood education are suspected unsatisfactory. This article discusses how to create reading interest and develop reading habit of the teachers of early childhood teachers as a means of improving their quality.
\end{abstract}

Key words: reading, interest, reading interest, quality improvement

\begin{abstract}
Abstrak
Dalam era infomasi dan ilmu pengetahuan dewasa ini, setiap orang berupaya mengembangkan keahliannya dengan mendapatkan informasi serta ilmu pengetahuan sebanyak dan secepat mungkin. orang akan ketingglan dan tidak dapat mengikuti kemajuan apabila tidak mempelajari dan mendayagunakan ilmu pengetahuan dan teknologi. Salah satu cara memperoleh informasi dan ilmu penegetahuan adalah dengan membaca dan masyarakat membaca adalah masyarakat-masyarakat belajar. Akan tetapi, minat dan kebiasaan membaca belum membudaya di Indonesia termasuk di kalangan pendidik dan tenaga kependidikan pendidikan nonformal, minat dan kebiasaan membaca belum seperti yang diharapkan.

Tulisan ini membahas cara meningkatkan minat membaca guru Pendidikan Anak Usia Dini sebagai salah satu upaya meningkatkan mutu mereka.
\end{abstract}

Kata-kata kunci : membaca, minat, minat baca, peningkatan mutu

\section{PENDAHULUAN}

\section{Latar Belakang Masalah}

Tenaga pendidik AUD (anak usia dini) adalah pendidik yang memberikan layanan pendidikan untuk anak usia dini yang berada pada rentangan usia $0-6$ tahun (UU Sisdiknas No.20 Tahun 2003, Penjelasan Pasal 28 Ayat 1). Tenaga pendidik ini harus mempunyai kompetensi yang mampu menggiring peserta didiknya menjadi generasi yang lebih unggul di masa depan. Kompetensi tersebut bisa didapat melalui suatu proses belajar baik di bangku kuliah, lingkungan masyarakat (pelatihan-pelatihan), dan melalui literatur-literatur yang bisa dibaca dan dipahami sehingga bisa menambah wawasan untuk tenaga pendidik tersebut.

\section{* Mahasiswa PG PAUD UNJ}

Tenaga pendidik PAUD yang mendapatkan kesempatan untuk mengenyam pendidikan di perguruan tinggi belum merata di seluruh Indonesia. Untuk mengatasi ketimpangan tersebut, pemerintah sudah melakukan berbagai upaya di antaranya memberikan pelatihan-pelatihan PAUD kepada tenaga pendidik tersebut. Akan tetapi, hal tersebut belumlah cukup menambah kompetensi tenaga pendidik PAUD di Indonesia. Tenaga pendidik tersebut harus dapat digiring menjadi pendidik yang gemar membaca buku, karena membaca buku adalah salah satu kegiatan yang efektif untuk meningkatkan wawasan dan ilmu pengetahuan tenaga pendidik sehingga dapat menambah kompetensi sebagai tenaga pendidik PAUD yang berkualitas. 
Melalui membaca buku, pendidik dapat mencari tahu bagaimana karakteristik peserta didik, bagaimana cara memberikan pendidikan yang baik terhadap peserta didiknya, bagaimana cara membuat perencanaan yang bisa menunjang tumbuh-kembang peserta didik, bagaimana cara membuat media dan materi yang mendukung tumbuh-kembang peserta didiknya, dan masih banyak lagi pengetahuanpengetahuan yang bisa diperoleh tenaga pendidik melalui kegiatan membaca buku. Membiasakan membaca buku memang bukanlah hal yang mudah untuk orang dewasa karena masa peka untuk mena-namkan minat baca sudah terlewati. Masa peka tersebut menurut Montessori (Crain, 2007: 6) berada sejak usia 4 tahun sampai 5 tahun. Akan tetapi, tidak ada kata terlambat untuk menumbuhkan minat membaca tenaga pendidik PAUD sehingga menjadi pendidik yang gemar membaca buku.

Minat membaca pendidik PAUD tersebut harus dapat ditumbuhkan melalui berbagai cara dan upaya yang bisa dilakukan oleh berbagai pihak (Pemerintah, Pakar Pemikir PAUD (Dosen dan praktisi PAUD), Pendidik PAUD, dan seluruh lapisan masyarakat yang peduli dengan PAUD). Melalui kerja sama tersebut diharapkan upaya menumbuhkan minat bahkan menjadi gemar membaca tenaga pendidik PAUD dapat menjadi alternatif terbaik untuk meningkatkan mutu tenaga pendidik PAUD di Indonesia.

Permasalahan kurangnya minat membaca tenaga pendidik PAUD karena beberapa alasan di antaranya, belum adanya program-program khusus untuk tenaga pendidik yang mewajibkan untuk membaca buku tentang PAUD atau buku-buku pengetahuan lainnya secara kontinu. Belum meratanya buku-buku PAUD yang bisa dibaca oleh para pendidik PAUD. Kurangnya sarana dan prasarana untuk membaca buku misalnya: tidak adanya perpustakaan kecil di POS-POS PAUD yang menyediakan buku-buku untuk dibaca oleh pendidik PAUD, kurangnya motivasi dari lingkungan sekitar tentang pentingnya membaca buku, dan belum meratanya sosialisasi dari berbagai pihak (pemerintah, pemerhati dan praktisi PAUD, dan tokoh-tokoh masyarakat) tentang pentingnya membaca

Hal yang lebih memprihatinkan lagi adalah masyarakat Indonesia yang tidak menyukai membaca salah satunya adalah karena buta aksara. Pemerintah sudah melakukan berbagai upaya untuk mengatasi buta aksara tersebut salah satunya melalui program kejar paket A. Akan tetapi diperlukan berbagai upaya lain yang bisa mengatasi permasalahan buta aksara tersebut salah satunya adalah mencetak generasigenerasi bangsa yang gemar membaca sehingga di masa mendatang masalah buta aksara ini sudah tidak ada lagi.

\section{KAJIAN TEORETIS}

\section{Minat}

Minat merupakan dimensi afektif yang mempunyai peranan penting dalam kehidupan seseorang. Mempunyai minat membuat seseorang mempunyai suatu pilihan dalam hidupnya. Ketika seseorang mempunyai pilihan maka akan timbul suatu semangat untuk melakukan apa yang sudah menjadi pilihannya.

Menurut Aiken (Abadi, 2006:3), minat merupakan kesukaan terhadap kegiatan melebihi kegiatan lainnya. Kegiatan tersebut dipilih sendiri dan menyenangkan sehingga terbentuk suatu kebiasaan. Adapun sifat dari minat itu tetap (persistent) karena minat bisa memuaskan kebutuhan penting seseorang. Kebutuhan penting tersebut apabila ditinggalkan akan terasa tidak nyaman atau tidak menyenangkan.

Sejalan dengan pendapatAiken, menurut Winkel (Winkel, 1991: 105) minat adalah kecenderungan subjek yang menetap, untuk merasa tertarik pada bidang studi atau pokok bahasan tertentu dan merasa senang mempelajari materi itu. Perasaan senang tersebut akan menimbulkan minat pada diri seseorang Selain minat yang akan muncul, perasaan senangpun bisa mengembangkan sikap positif. Minat dan sikap positif tersebut cenderung membuat seseorang merasa bahagia menjalani kehidupan ini.

Menurut Hurlock (Hurlock, 1999:114), minat adalah sumber motivasi yang akan mengarahkan seseorang pada apa yang mereka lakukan bila diberi kebebasan untuk memilihnya. Bila mereka melihat sesuatu itu mempunyai arti bagi dirinya, mereka akan tertarik terhadap sesuatu itu yang pada akhirnya nanti menimbulkan kepuasan pada dirinya. Kepuasan tersebut menjadi salah satu sumber kebahagiaan seseorang. Apabila seseorang sudah merasa bahagia, biasanya mereka akan lebih bisa mengenal kualitas di dalam dirinya yang mendorongnya untuk menjadi individu yang lebih baik lagi.

Berdasarkan pendapat para ahli tersebut di atas, pengertian minat dapat dideskripsikan sebagai sumber motivasi untuk melakukan apa yang sudah menjadi pilihannya. Ketika minat tersebut sudah muncul maka 
akan sangat sulit untuk menghilangkannya karena sifat dari minat itu tetap (Persistent).

\section{Membaca}

Menurut Masjidi (Masjidi, 2007:49), membaca merupakan salah satu jenis kemampuan berbahasa tulis yang bersifat reseptif. Disebut reseptif karena ketika seseorang melakukan kegiatan membaca, seseorang tersebut dapat memperoleh informasi, ilmu pengetahuan, serta pengalaman-pengalaman baru. Apa yang sudah di dapatkan dari kegiatan membaca tersebut, membuat seseorang bisa meningkatkan kualitas dirinya.

Menurut Rudel (Morrow, 1993:66), "reading as the use of one's language ability to decode andcomprehend". Pengertian membaca menurut Rudel tersebut adalah membaca sebagai salah satu penggunaan bahasa untuk membaca simbol dan memahaminya. Seseorang yang mampu membaca simbol tanpa mengetahui maknanya belum dikatakan membaca. Ketika seseorang ingin membaca, ia harus dapat membaca simbol-simbol dalam bacaan tersebut dan mampu memahami apa yang sudah dibacanya. Menurut pendapat Goodman (Bromley, 1992:202), membaca dapat diartikan sebagai berikut:

Reading is an active cognitive process of interacting with print and monitoring comprehension to establish meaning. Reading is the instantaneuos recognition of various written symbols, simultaneuos asociation of these symbol with existing knowledge and comprehension of the information and ideas communicated. When a reader interacts with print; his prior knowledge combined with the visual (written) information result in his comprehension.

Pengertian membaca menurut Goodman tersebut dapat diartikan bahwa membaca adalah proses interaksi kognitif dengan gambar dan pemahaman untuk mengambil sebuah arti. Membaca adalah pengenalan beberapa simbol yang tertulis, peniruan gabungan simbol-simbol dengan pengetahuan yang ada dan pemahaman dari informasi dan ide yang berhubungan.

Menurut Wilson dan Peter (Clearly \& Miller, 1993:284), membaca adalah proses makna melalui interaksi dinamis di antara pengetahuan pembaca yang telah ada, informasi yeng telah dinyatakan oleh bahasa tulis, dan konteks sosial. Dalam memahami suatu bacaan seseorang harus menggunakan pengetahuan yang sudah dimilikinya. Ketika membaca, indera penglihatan seseorang mengenali tulisan dan pikirannya menghubungkan pada maknanya.

Berdasarkan beberapa pendapat para ahli tersebut di atas, membaca dapat dideskripsikan sebagai proses interaksi kognitif untuk merespon tulisan dengan membaca simbol dan memahami artinya sehingga dapat diperoleh informasi, ilmu pengetahuan, dan pengalaman-pengalaman baru yang bisa meningkatkan kualitas pembacanya menjadi individu yang lebih baik lagi.

\section{Pengertian Minat Membaca}

Minat baca adalah hal positif yang harus ditumbuhkan sedini mungkin. Karena bangsa yang maju adalah bangsa yang sumber daya manusianya menyukai kegiatan membaca. Melalui membaca seseorang bisa menggali ilmu pengetahuan sehingga bisa meningkatkan kulitas dirinya.

Menurut Ginting (Ginting, 2005:30), minat baca adalah tingkat perasaan senang yang sangat kuat dalam kegiatan membaca yang membutuhkan stimulus untuk mewujudkannya menjadi suatu kebiasaan. Apabila seseorang sudah mempunyai keterampilan membaca, akan tetapi tidak diberikan stimulus untuk membuatnya rutin membaca setiap hari minat bacanya tidak akan mengalami peningkatan.

Menurut Meckel (Rahman, 2009:7), minat baca merupakan kecenderungan, perhatian, dan keinginan untuk melihat tulisan atau bacaan, lebih mengetahui atau mendalami apa yang dibacanya dengan baik. Minat mempunyai pengaruh yang besar terhadap membaca, jika bahan bacaan atau tulisan yang akan dibaca tidak sesuai dengan minatnya, bahan bacaan atau tulisan tersebut tidak akan dibacanya dengan sepenuh hati karena tidak ada daya tarik dari bahan bacaan tersebut.

Menurut Jennings (Jennings, 2006:17), minat baca adalah virus membaca yang ditularkan oleh lingkungan di sekitarnya. Lingkungan memberikan contoh tentang betapa menyenangkannya melakukan kegiatan membaca. Selain itu, membacapun mempunyai manfaat untuk membuka cakrawala pemikiran dan untuk meningkatkan kualitas kehidupan.

Berdasarkan beberapa pendapat ahli di atas, minat baca dapat dideskripsikan sebagai keinginan yang kuat untuk melakukan kegiatan membaca dan memahami apa yang dibacanya, dan keinginan tersebut muncul karena adanya stimulus dari lingkungan sehingga mampu menjadikan kegiatan membaca sebagai kebiasaan sehari-hari.

\section{Pentingnya Menumbuhkan Minat Membaca}

Kemajuan suatu bangsa bisa dilihat dari tingkat minat membaca dari warga negaranya. Sejarah kemajuan negara-negara di dunia seperti, Amerika, Jepang, Korea, dan negara -negara lainnya berawal dari ketekunannya membaca. Masyarakat di negara tersebut dididik untuk selalu merasa tidak puas dengan kemajuan yang telah dicapai sehingga mendorongnya untuk terus menggali ilmu pengetahuan yang salah 
satunya melalui kegiatan membaca. Hal tersebut menjadi bukti konkret bahwa buku adalah kunci perubahan dunia atau buku diistilahkan sebagai jendela peradaban.

Menurut Suherman (Suherman, 2009:10), membangun masyarakat yang gemar membaca tidak hanya menyediakan buku-buku yang bisa dibaca saja, akan tetapi membangun pemikiran, perilaku, dan budaya dari generasi yang tidak suka membaca menjadi generasi yang suka membaca. Melalui cara tersebut kreativitas dan transfer pengetahuan bisa berlangsung dan berkembang.

Menumbuhkan minat membaca merupakan suatu langkah untuk menciptakan masyarakat yang gemar membaca. Minat baca ini perlu ditumbuhkan sedini mungkin agar lebih mudah menjadikan membaca sebagai kebiasaan hidup sehari-hari. Apabila membaca sudah menjadi kebutuhan hidup sehari-hari, akan tercipta budaya membaca.

Menumbuhkan minat membaca penting dilakukan terutama untuk para pendidik anak usia dini. Pendidik tersebut adalah tangan-tangan pemerintah yang mengemban tugas untuk mencerdaskan peserta didiknya agar kelak menjadi generasi unggul yang mampu mengharumkan bangsanya di dunia internasional. Peserta didik anak usia dini tersebut berada pada masa peka untuk diberikan stimulus edukatif yang salah satunya ditanamkan kecintaan membaca sejak dini. Apabila pendidik anak usia dini tidak gemar membaca bagaimana mereka dapat menjadi model yang baik untuk peserta didiknya. Hal yang perlu diketahui dan dipahami oleh pendidik anak usia dini adalah bahwa anak usia dini itu belajar melalui proses imitasi dan repetisi (Crain, 2007:6). Proses imitasi, yaitu anak akan cenderung melakukan apa yang dilihat di sekelilingnya. Misalnya, pendidik di sekolah setiap hari sering melakukan kegiatan membaca dan peserta didik melihat kebiasaan tersebut, lalu termotivasi untuk menirunya. Proses repetisi, yaitu membaca buku yang dilakukan berkali-kali akan menjadi kebiasaan yang alamiah dan akan merasa tidak nyaman apabila tidak melakukannya.

Melalui kegiatan membaca buku, pendidik anak usia dini bisa terus menggali wawasan dan ilmu pengetahuan tentang PAUD sehingga bisa meningkatkan kualitasnya sebagai pendidik. Banyak sekali buku-buku yang bisa menambah wawasan pendidik terutama untuk mengatasi berbagai kendala mengajar anak usia dini. Mengajar anak usia dini tidak hanya mengajarkan anak usia dini membaca dan menyanyi saja, tetapi ada berbagai potensi kecerdasan yang harus dikembangkan dari setiap anak usia dini. Hal tersebut akan diketahui salah satunya melalui membaca buku-buku tentang PAUD.

Ada beberapa faktor yang bisa mendukung pendidik anak usia dini untuk menumbuhkan minat membacanya, di antaranya: faktor motivasi, faktor lingkungan, dan faktor bahan bacaan. Faktor motivasi, yaitu dorongan dari dalam diri para pendidik untuk terus belajar dan selalu merasa tidak cukup dengan ilmu yang sudah didapat sehingga mendorongnya untuk selalu belajar melalui membaca buku. Orang-orang terdekat para pendidik dapat memberikan dorongan untuk membaca buku sehingga akan menjadi sumber motivasi untuk para pendidik tersebut.

Faktor lingkunganpun bisa menjadi hal terpenting yang bisa menumbuhkan minat membaca pendidik anak usia dini. Lingkungan yang dapat menyediakan sarana dan prasarana membaca akan mempermudah pendidik menumbuhkan minat bacanya. Hal ini tidak terlepas dari kerja sama berbagai pihak terutama pemerintah dan masyarakat yang peduli PAUD untuk mewujudkan penyediaan sarana dan prasarana membaca dan membuat berbagai program atau kegiatan yang menuntut pendidik untuk membaca buku.

Faktor bahan bacaan, yaitu bahan bacaan yang akan dibaca oleh pendidik AUD harus disesuaikan dengan pengetahuan yang ingin diketahui oleh pendidik tersebut (berhubungan dengan bidang ilmu pengetahuan AUD). Selanjutnya, Masalah penggunaan bahasa dalam buku-buku tersebut dapat menjadi penghalang bagi pendidik untuk membacanya. Misalkan, buku-buku PAUD yang tersedia menggunakan bahasa Inggris sedangkan pendidik yang akan membacanya tidak menguasai bahasa Inggris sehingga membuat beberapa pendidik malas untuk membacanya.

Berdasarkan pemaparan faktor yang mendukung minat membaca pendidik anak usia dini tersebut di atas, diharapkan dapat menjadi solusi untuk menumbuhkan minat membaca pendidik anak usia dini sehingga pendidik tersebut dapat menjadi pendidik yang berkualitas.

\section{PEMBAHASAN}

Menumbuhkan minat membaca tenaga pendidik PAUD memang merupakan hal yang tidak mudah karena masa peka untuk ditanamkan minat membaca sudah terlewati, serta membaca sendiri belum menjadi 
budaya masyarakat Indonesia pada umumnya. Data Badan Pusat Statistik tahun 2006 menunjukkan bahwa masyarakat Indonesia belum menjadikan kegiatan membaca sebagai sumber utama mendapatkan informasi. Masyarakat lebih memilih menonton televisi $(85,9 \%)$, dan/atau mendengarkan radio $(40,3 \%)$ daripada membaca koran atau buku-buku lainnya $(23,5 \%)$. Data Biro Pusat Statistik (BPS) ini menunjukkan bahwa membaca adalah kegiatan yang masih jarang dilakukan oleh masyarakat Indonesia pada umumnya.

Menjadikan generasi yang gemar membaca sejak dini adalah bagian dari tugas pendidik PAUD sehingga pendidik PAUD harus memberikan contoh baik kepada peserta didiknya yaitu gemar membaca buku. Pendidik yang belum menyukai membaca buku dapat ditumbuhkan minat membacanya melalui berbagai upaya, di antaranya: (1) memfasilitasi bukubuku yang bisa di baca oleh pendidik PAUD, (2) menyediakan sarana dan prasarana membaca buku misalkan dengan membangun perpustakaanperpustakaan kecil yang merata di setiap POS-POS
PAUD di seluruh Indonesia, (3) Menyelenggarakan kegiatan diskusi tentang buku PAUD setiap bulan di setiap POS-POS PAUD sehingga bisa saling bertukar informasi dan pengalaman, (4) Mewajibkan pendidik untuk membaca satu buku atau buletin PAUD setiap minggu, (5) Mengikuti berbagai pelatihan yang bisa memotivasi minat membaca dan minat untuk terus belajar tentang ilmu PAUD, dan (6) memberikan apresiasi atau penghargaan kepada pendidik yang dapat menjadikan membaca sebagai kebutuhan sehari-hari. Upaya-upaya tersebut di atas bisa menjadi suatu alternatif peningkatan minat membaca tenaga pendidikAUD yang akan berkolerasi menjadi pendidik AUD yang berkualitas. Karena minat membaca AUD bisa menjadi pondasi yang akan menjadikan mereka sebagai pendidik yang mempunyai wawasan luas, sehingga mutu sebagai pendidikpun bisa lebih meningkat.

Berdasarkan beberapa upaya tersebut, diharapkan membantu pemerintah untuk menjadikan para pendidik AUD di seluruh Indonesia tumbuh minat membacanya sehingga membaca menjadi salah satu solusi yang efektif dalam upaya peningkatan mutu tenaga pendidik AUD di Indonesia

\section{KESIMPULAN}

\section{Kesimpulan}

Berdasarkan uraian pembahasan materi di atas dapat disimpulkan bahwa menumbuhkan minat membaca para pendidik PAUD penting dilakukan karena bisa menjadi salah satu cara untuk meningkatkan mutu tenaga pendidik PAUD di Indonesia. Saran

Berdasarkan paparan di atas, penulis memberi beberapa saran, sebagai berikut.

Pertama, untuk Pendidik Anak Usia Dini, para PAUD hendaknya mulai dari sekarang memotivasi diri dan teman-temannya untuk mulai membiasakan membaca buku agar wawasan dan ilmu pengetahuannya terus bertambah.

Kedua, untuk pakar PAUD khususnya yang masih mentransfer ilmu PAUD nya di perguruan tinggi diharapkan dapat memotivasi para mahasiswanya untuk bisa mengabdikan ilmu yang telah didapatkan di bangku kuliahnya kepada masyarakat luas, tidak hanya di ibu kota saja, tetapi harus berani ke pelosok-pelosok daerah yang secara umum masih sangat awam akan ilmu PAUD dan secara khusus mengenai pentingnya minat membaca.

Ketiga, untuk masyarakat, diharapkan bisa menjadi partner yang baik untuk menciptakan budaya membaca di lingkungan sekitarnya sehingga akan membantu memudahkan pendidik untuk menumbuhkan minat bacanya.

Keempat, untuk Pemerintah, diharapkan dapat menjadi kapten yang baik dalam mensukseskan program menumbuhkan minat membaca masyarakat khususnya bagi para pendidik PAUD, sehingga tujuan peningkatan mutu pendidik PAUD di seluruh Indonesia dapat tercapai.

\section{DAFTAR PUSTAKA}

Abadi, A. (2006). Upaya meningkatkan minat baca pada anak. Diakses tanggal 05 Januari 2009 dari http:/ /www.geocitiec.com/motivasi mi-nat baca.html

Bromley, K.D. (1992). Language art: Exploring connection. Boston: Allyn Bacon.
Cleary, M. \& D. Linn, M. (1993). Linguistics for teachers. New York: Mc Graw-Hill.

Crain, W. (2007). Teori perkembangan konsep dan aplikasi. Yogyakarta: Pustaka Pelajar.

Ginting, V. (2005). Keterampilan membaca dan minat 
baca. Diakses tanggal 05 Januari 2009 dari http:/ lalmaipi.com/journal

Hurlock, E.B. (1999). Perkembangan anak jilid II. Jakarta: Erlangga.

Jennings, P. (2006). Agar anak anda tertular virus membaca. Bandung: Mizan Media Utama.

Masjidi, N. (2007). Agar anak suka membaca. Yogyakarta: Media Insani.

Morrow, L.Ml. (1993). Literacy development in the early years. Boston: Allyn and Bacon.
Rahman, A. (2009). Motivasi belajar dan minat membaca siswa. Diakses tanggal 20 Februari 2009 dari http://makalah2009.word-press.com

Suherman. (2009). Perpustakaan sebagai jantung sekolah. Bandung: MQS Publishing.

UU RI No. 20 Tahun 2003. (2008). Sistem pendidikan nasional. Jakarta: Sinar Grafika, 2008.

Winkel, W.S. (1991). Psikologi pengajaran. Jakarta: Grasindo. 